\title{
Otonomi Daerah sebagai Instrumen Pertumbuhan Kesejahteraan dan Peningkatan Kerjasama Antardaerah
}

\author{
AHMAD SURKATI \\ Fakultas Hukum, Universitas Sultan Ageng Tirtayasa, Jl. Raya Jakarta KM 4 Pakupatan Serang, Banten \\ email: achmad.surkati@yahoo.com
}

\begin{abstract}
Regional autonomy legislation in terms of organizing his administration can not be separated by the application of the prinsiple of decentralization, deconcentrationand Co-principle (Medebewind). Basic Act 1945 section 18, 18 A andB, where the division ofthisarea are givenautonomy to takecare of their own household. Zoning will be associated with geography and the potential in each region that are not comparable. Application of the principle of local autonomy in order to keep the Republik of Indonesia between central goverment and local goverment. Therefore, the question is how the application of the principle of regional cooperation can improve the welfare andinter-national regions with the potential conditions that are not comparableas the geographic and human resources. Regional autonomy as an instrument to realize prosperity in an ideal form of cooperation.
\end{abstract}

Key words: autonomy, growth, welfare.

\begin{abstract}
Abstrak. Otonomi daerah dalam Peraturan Perundang-undangan dari segi penyelenggaraan pemerintahannya tidak terlepas dengan proses penerapan Asas Desentralisasi, Asas Dekonsentrasi dan Tugas Pembantuan (Medebewind). Undang-Undang dasar 1945 pasal 18, 18 A dan $B$, dimana pembagian daerah ini diberikan hak otonomi untuk mengurusi rumah tangganya sendiri. Pembagian daerah akan berkaitan dengan geografi dan potensi di wilayahnya masing-masing yang tidak berimbang. Penerapan asas otonomi daerah dalam rangka menjaga Negara Kesatuan Republik Indonesia antara pemerintahan pusat dan pemerintahan daerah. Oleh karena itu, persoalannya adalah bagaimana penerapan asas otonomi daerah dapat meningkatkan kesejahteraan dan kerjasama antardaerah secara nasional dengan kondisi potensi wilayah yang tidak berimbang seperti keadaan geografi dan sumber daya manusianya. Otonomi daerah sebagai salah satu instrumen untuk mewujudkan kesejahteraan dalam bentuk kerjasama yang ideal.
\end{abstract}

Kata kunci: otonomi, pertumbuhan, kesejahteraan.

\section{Pendahuluan}

Negara Indonesia adalah negara kesatuan sebagai negara kepulauan yang terbagi menjadi daerah-daerah otonom dengan kondisi geografi dan potensi yang berbeda tentunya dalam proses lajunya pertumbuhan kesejahteraan masyarakat dan pembangunan serta kerjasama antar daerah tidak akan berimbang, oleh karenanya perlu peraturan daerah yang dibuat oleh DPRD dibahas bersama-sama dengan Kepala Daerah (Gubernur, Bupati dan Walikota) untuk mendapat persetujuan bersama sebagai instrumen tertulis dalam melaksanakan prinsip dan asas otonomi (Desentralisasi, Dekonsentrasi dan Tugas Pembantuan), yang diharapkan dapat mempercepat lajunya pertumbuhan masyarakat di daerah dalam berbagai bidang terutama bidang kesejahteraan masyarakat dan kerjasama pembangunan antar daerah semakin meningkat, hal ini sangat menarik, diperlukan kajian-kajian dalam penelitian untuk mencari format ideal dalam bentuk konsepsional. (UU No. 10 Tahun 2004 tentang Pembentukan Peraturan Perundang-undangan Pasal 1 ayat (7). Indonesia sebagai negara kesejahteraan (Welfare State) dalam pelaksanaan otonomi daerah tujuannya adalah melalui pemerataan pelaksanaan pembangunan di seluruh wilayah Negara Indonesia (B. Hestu Cipto Handoyo, 1998: 9-10. Sesuai dengan pendapat Bagir Manan (B.Hestu Cipto Handoyo, 1998: 13) bahwa fungsi utama pemerintah daerah memberikan pelayanan untuk kesejahteraan masyarakat dalam bentuk 
penyediaan atau pemenuhan kebutuhan seperti kesehatan, kebersihan, dan sebagainya.

Instrumen secara tertulis dalam melaksanakan otonomi daerah telah diatur dalam Undang-Undang Nomor 32 tahun 2004 tentang Pemerintahan Daerah yang mengatur bahwa hakekat dari otonomi daerah adalah untuk kesejahteraan masyarakat serta terlaksananya kerjasama dalam pembangunan antar daerah, maka yang menjadi masalah dalam penelitian ini adalah bagaimana konstruksi konsepsional otonomi daerah sebagai salah satu instrumen peningkatan lajunya pertumbuhan kesejahteraan masyarakat di Indonesia dan Bagaimana format ideal kerjasama pembangunan antar daerah di Indonesia berdasarkan Undang-Undang Nomor 32 Tahun 2004

Menurut $\mathrm{H}$, Zainuddin Ali, bahwa pada dasarnya melakukan penelitian itu adalah suatu upaya pencarian, yang menimbulkan pertanyaan apakah yang dicari itu, yang dicari adalah pengetahuan atau pengetahuan yang benar, $(\mathrm{H}$. Zainuddin Ali,: 1) senada dengan hal tersebut menurut Bambang Sunggono bahwa penelitian itu merupakan suatu usaha pencarian, melalui suatu proses atau prosedur dan tata cara yang sistematis atau metoda untuk mendapatkan data, mengolah dan menyimpulkan yang dapat memecahkan suatu masalah (Sunggono, 2009: 27).

Pada penelitian ini digunakan metode deskriptif analitis melalui pendekatan yuridis normatif dengan melakukan kajian terhadap kaidah-kaidah hukum atau peraturan perundang-undangan yang berkaitan dengan otonomi daerah sebagai pendorong laju pertumbuhan kesejahteraan masyarakat dan peningkatan kerjasama pembangunan antar daerah di Indonesia.

Sumber data dalam penelitian ini berupa Bahan hukum primer, seperti UUD 1945, UndangUndang Nomor 32 Tahun 2004 tentang Pemerintahan Daerah, Peraturan Pemerintah RI Nomor 50 Tahun 2007 tentang Tata Cara Pelaksanaan Kerjasama Daerah, Peraturan Pemerintah RI Nomor 7 Tahun 2008 Tentang Dekonsentrasi dan Tugas Pembantuan. Bahan hukum sekunder, seperti pandangan dan pendapat para ahli, akademisi, praktisi, buku-buku maupun literatur lainnya. Bahan hukum tersier, seperti kamus, ensiklopedia, jurnal dan data dari internet.

Metode pengumpulan datanya berupa kajian pustaka, sedangkan analisis datanya adalah secara kualitatif yang hasilnya disajikan dalam bentuk kalimat yang tersusun secara sistematis, jelas, rinci, sehingga memudahkan dalam pemberian arti, dalam mengolah dan menganalisa data dilakukan dengan analisa kualitatif berdasarkan sajian konstruksi data (pengkajian hasil penelitian) bersifat deskriptif (Soeryono Soekanto, 1986: 6).

\section{Landasan Teori}

Kekuasaan dan kewenangan merupakan implementasi dan amanat dari Undang-Undang Dasar 1945 baik dalam hasil amandemen maupun pada naskah yang lama, turunannya adalah Undang-Undang sebagai peraturan perundangundangan organik, kaitan dengan penelitian ini Undang-Undang Nomor 32 Tahun 2004, tentang Otonomi Daerah, yang didalamnya mengandung teori dan asas serta prinsip kekuasaan dan kewenangan (Asas Desentralisasi, Dekonsentrasi dan Tugas Pembantuan), di mana kekuasaan ini sama dengan kedaulatan yang melekat pada subyek hukum tidak dapat dibagi-bagi dan dapat dilimpahkan serta diberikan sesuai dengan kewenangan dan kehendaknya.

Kekuasaan secara umum diartikan sebagai suatu kemampuan untuk mempengaruhi orang lain/kelompok lain sesuai dengan pemegang kekuasaan itu sendiri dalam suatu pemerintahan negara. Berkaitan dengan kekuasaan politik Mariam Budiardjo mengatakan bahwa "Merupakan kemampuan untuk mempengaruhi kebijaksanaan umum (pemerintah) baik terbentuknya maupun akibat-akibatnya sesuai dengan tujuan pemegang kekuasaan sendiri, kekuasaan pemerintahan tidak hanya mencakup kekuasaan untuk memperoleh ketaatan dari warga masyarakat, tapi juga menyangkut pengendalian orang lain, dengan tujuan untuk mempengaruhi tindakan dan aktifitas di bidang administratif (eksekutif), legislatif dan yudikatif, Kekuasaan bila diartikan secara yuridis maka kekuasaan ini disebut kedaulatan sebagaimana yang dikemukakan oleh Jean Bodin.

UUD 1945 Pasal 1 ayat (1), bahwa "Negara Indonesia adalah negara kesatuan yang berbentuk Republik", (UUD 1945 dalam Naskah Lama dan Hasil Amandemen). istilah negara kesatuan (bersusun tunggal) adalah susunan negaranya hanya terdiri dari satu negara, tidak mengenal konsep negara bagian dalam penyelenggaraan pemerintahan negaranya. (Pasal 18, 18A, dan 18B UUD 1945 Hasil Amandemen).

Negara kesatuan, hanya ada satu pemerintah yaitu Pemerintah Pusat yang mempunyai kekuasaan serta kewenangan tertinggi dalam bidang pemerintahan negara, menetapkan kebijakan pemerintah dan melaksanakan pemerintahan negara baik di pusat maupun di daerah-daerah, (Soehino, 2000: 24) Negara Indonesia adalah negara kepulauan yang paling banyak pulaunya dibandingkan negara-negara lain, oleh karena itu dengan konsep otonomi daerah paling tepat dalam kerangka pelaksanaan Pemerintahan Negara Kesatuan, hanya persoalannya adalah bagaimana dalam negara kesatuan ini untuk meringankan tugas-tugas pemerintahan pusat dapat mendorong lajunya 
pertumbuhan kesejahteraan masyarakat atau peningkatan kerjasama pembangunan antar daerah di Negara Kesatuan Republik Indonesia, dengan kondisi geografi, potensi wilayah dan SDM yang berbeda, konsep dan format ideal yang bagaimana yang baik berdasarkan Undang-Undang Nomor 32 Tahun 2004 dalam penerapan asas Desentralisasi, Dekonsentrasi serta Tugas Pembantuan yang diatur dalam undang-undang tersebut.

Otonomi substansinya kewenangan mengatur urusan rumah tanganya sendiri, sedangkan daerah otonom adalah kesatuan masyarakat hukum yang mempunyai batas wilayah. Menurut Moh. Kusnadi dan Bintan R. Saragih bahwa istilah otonomi secara etimologi dari Bahasa Yunani, yaitu Auto (sendiri) dan Nomos (peraturan) atau Undang-Undang (Dharma Setyawan Salam, 2004 : 88). menurut Muslim bahwa "otonomi" diartikan sebagai pemerintahan sendiri (Dharma Setyawan Salam, 2004: 88) kemudian menurut Fernandez adalah pemberian hak, wewenang dan kewajiban kepada daerah yang memungkinkan daerah tersebut mengatur dan mengurus rumah tangganya sendiri untuk meningkatkan daya guna dan hasil guna penyelenggaraan pemerintahan dalam rangka pelayanan terhadap masyarakat dan pelaksanaan pembangunan (Dharma Setyawan Salam, 2004 : 88). Wewenang di sini merupakan substansi daerah otonom yang diselenggarakan secara konseptual oleh pemerintah daerah, menurut Joeniarto bahwa dalam negara kesatuan semua urusan negara menjadi wewenang sepenuhnya pemerintah (pusat) nya, kalau negara yang bersangkutan mempergunakan asas Desentralisasi di mana di daerah-daerah dibentuk pemerintah lokal yang berhak mengatur dan mengurus rumah tangga sendiri, kepadanya dapat diserahkan urusan tertentu untuk diurus sebagai urusan rumah tangganya sendiri (Titik Tri Wulantutik, 2006: 177-178).

Pemahaman tentang Negara Kesatuan menurut Moh. Kusnadi dan Bintan R. Siragih bahwa yang disebut Negara Kesatuan apabila kekuasaan Pemerintah Pusat dan Pemerintah Daerah tidak sama dan tidak sederajat dan kewenangan pembentukan adalah kewenangan Legislatip pusat. Kemudian kekuasaan di daerah bersifat Derevatif (tidak langsung) dan dalam bentuk otonom yang luas (Titik Tri Wulantutik, 2006; 177-178).

Presiden sebagai Kepala Pemerintahan Pusat, sesuai dengan kekuasaan dan kewenangan dalam Undang-Undang Dasar 1945 (lihat UndangUndang Nomor 32 Tahun 2004), menganut 3 asas dalam penyelenggaraan pemerintahannya, yaitu: Desentralisasi adalah penyerahan wewenang pemerintahan oleh pemerintah kepada daerah otonom untuk mengatur dan mengurus urusan pemerintahan dalam sistem Negara Kesatuan Republik Indonesia; Dekonsentrasi adalah pelimpahan wewenang pemerintahan oleh pemerintah kepada gubernur sebagai wakil pemerintah dan/atau kepada instansi vertikal di wilayah tertentu; Tugas Pembantuan adalah penugasan dari pemerintah kepada daerah dan/ atau desa; dari pemerintah provinsi kepada kabupaten/kota dan/atau desa serta pemerintah kabupaten/kota kepada desa untuk melaksanakan tugas tertentu.

Bila dilihat dari sisi kepentingan pemerintah pusat, menurut Smith (1985) sedikitnya ada tiga tujuan utama dari desentralisasi, yaitu (Syamsudin Haris, 2006: 68): Pertama, melalui praktek desentralisasi, diharapkan masyarakat akan belajar mengenali dan memahami berbagai persoalan sosial, ekonomi dan politik yang mereka hadapi.

Kedua, to provide training in political leadership (untuk latihan kepemimpinan). Tujuan ini berangkat dari asumsi dasar bahwa Pemerintah Daerah merupakan wadah yang paling tepat untuk training bagi para politisi dan birokrat, sebelum mereka menduduki berbagai posisi penting di tingkat nasional. Ketiga, desentralisasi dari sisi kepentingan Pemerintah Pusat adalah to create political stability (untuk menciptakan stabilitas politik). Melalui kebijaksanaan desentralisasi akan mampu mewujudkan kehidupan sosial yang harmonis dan kehidupan politik yang stabil.

Selanjutnya dilihat dari kepentingan Pemerintah Daerah, menurut Smith (1985), sedikitnya ada tiga tujuan utama dari desentralisasi, yaitu: Pertama, desentralisasi tujuannya untuk mewujudkan apa yang disebut dengan political equality. Ini berarti, melalui pelaksanaan desentralisasi diharapkan akan lebih membuka kesempatan bagi masyarakat untuk berpartisipasi dalam berbagai aktifitas politik di tingkat lokal. Kedua, desentralisasi dari sisi kepentingan Pemerintah Daerah adalah local accountability. Maksudnya, melalui pelaksanaan desentralisasi diharapkan akan dapat tercipta peningkatan kemampuan Pemerintah Daerah dalam memperhatikan hak-hak dari komunitasnya, yang meliputi hak untuk ikut serta dalam proses pengambilan keputusan dan implementasi kebijakan di daerah, serta hak untuk mengontrol pelaksanaan Pemerintah Daerah itu sendiri.

Ketiga, desentralisasi dari sisi kepentingan Pemerintah Daerah adalah local responsiveness. Asumsi dasar dari tujuan desentralisasi yang ketiga ini adalah karena Pemerintah Daerah dianggap lebih mengetahui berbagai masalah yang dihadapi oleh komunitasnya, maka melalui pelaksanaan desentralisasi diharapkan akan menjadi jalan terbaik untuk mengatasi dan sekaligus meningkatkan akselerasi dari pembangunan sosial dan ekonomi di daerah.

Menurut C.S.T Kansil (2003: 142), asas Desentralisasi adalah yang menyatakan penyerahan 
sejumlah urusan pemerintahan dari Pemerintah Pusat atau Pemerintah Daerah yang lebih tinggi kepada Pemerintah Daerah tingkat yang lebih rendah sehingga menjadi urusan rumah tangga daerah tersebut, sedangkan asas Dekonsentrasi adalah pelimpahan wewenang dari Pemerintah Pusat kepada kepala wilayah atau kepala instansi vertikal tingkat yang lebih tinggi kepada pejabatpejabatnya di daerah.

Kebijakan penerapan asas Desentralisasi dan Dekonsentrasi ada beberapa tujuan dan manfaatnya, yaitu: (1) Segi hakekatnya, Desentralisasi dapat mencegah terjadinya penumpukan (consentration of power) dan pemusatan kekuasaan (centralized of power) dapat menimbulkan tirani; (2) Segi politik, Desentralisasi merupakan wahana untuk pendemokratisasian kegiatan pemerintahan; (3) Segi teknis organisatoris, Desentralisasi dapat menciptakan pemerintahan yang lebih efektif dan efisien; (4) Segi sosial, Desentralisasi dapat membuka peluang partisipasi dari bawah yang lebih efektif dan berkembangnya kaderisasi kepemimpinan yang bertanggungjawab karena proses pengambilan keputusan tersebar di pusat-pusat kekuasaan di seluruh daerah; (5) Segi budaya, Desentralisasi diselenggarakan agar perhatian dapat sepenuhnya di berikan kepada kekhususan-kekhususan yang terdapat di daerah, sehingga keanekaragaman budaya dapat terpelihara dan sekaligus didayagunakan sebagai modal yang mendorong kemajuan pembangunan dalam bidang-bidang lainnya; (6) Segi kepentingan pembangunan ekonomi, karena pemerintahan daerah dianggap lebih banyak tahu dan secara langsung berhubungan kepentingan di daerah, maka dengan kebijakan Desentralisasi, pembangunan ekonomi dapat terlaksana dengan lebih cepat dan dengan ongkos yang lebih murah.

Pada prinsipnya penyelenggaraan pemerintahan dalam rangka Desentralisasi dan otonomi daerah adalah untuk meningkatkan kesejahteraan masyarakat, karena dalam pelaksanaan otonomi daerah dan Desentralisasi telah diberikan ruang yang cukup untuk melaksanakan kerjasama antar daerah yang didasarkan pada prinsip efisiensi dan efektifitas. Pengelolaan kerjasama antar daerah tersebut dapat dilaksanakan oleh badan pengelola yang pengaturannya dan pembentukannya dapat diatur dengan keputusan bersama antar daerah. Pemerintah Pusat dapat menyediakan pelayanan publik apabila daerah belum/tidak melakukan kerjasama antar daerah. Kerjasama akan terjadi ketika pihak yang bekerjasama mendapatkan keuntungan dari kerjasama tersebut (simbiose mutualisme) atau paling tidak ada pihak yang diuntungkan tapi tidak ada pihak yang dirugikan (simbiose komensalisme). Karena itu, bentuk kerjasama itu juga dipengaruhi keunggulan komparatif (kepemilikan sumber) dan keunggulan kompetitif (efisiensi).

Kerjasama akan saling menguntungkan jika terjadi kesesuaian pada kedua keunggulan tersebut antar pihak yang bekerjasama. Sebaliknya sifat saling menggantikan (subtitution) memunculkan persaingan (competition) antar pihak, sehingga bentuk kerjasamanya adalah spesialisasi yang merupakan kesepakatan antar pihak. Dalam pasal 2 Peraturan Pemerintah Nomor 50 Tahun 2007 Tentang Tata Cara Pelaksanaan Kerjasama Daerah antara lain: kerjasama daerah dilakukan dengan prinsip efisiensi, efektivitas, sinergi, saling menguntungkan, kesepakatan bersama, itikad baik, mengutamakan kepentingan nasional dan keutuhan wilayah Negara Kesatuan Republik Indonesia, kesamaan, kedudukan, transparansi, keadilan dan kepastian hukum, sedangkan pasal 4 mengatur tentang objek kerjasama daerah adalah seluruh urusan pemerintahan yang telah menjadi kewenanangan daerah otonomi dan dapat berupa penyediaan pelayanan publik.

Tujuan dan manfaat penelitian dapat dijadikan dasar pengambil kebijakan dalam rangka pelaksanaan atau daerah yang dapat mensejahterakan masyarakat serta membangun kerjasama antar daerah di Indonesia. Kemudian diharapkan dapat bermanfaat secara khusus memberikan informasi baru kepada pengamat dan pengajar di bidang hukum pemerintahan daerah lebih khusus mengenai otonomi daerah, serta memberikan masukan kepada pemerintahan melalui Dewan Perwakilan Republik Indonesia, mengenai format otonomi daerah yang dapat mensejahterakan rakyat serta membangun kerjasama dan menemukan teori baru berkaitan dengan format otonomi daerah yang dapat mensejahterakan masyarakat dan membangun kerjasama daerah.

Keutamaan dalam penelitian ini terletak pada pelaksanaan otonomi di daerah yang ada di Indonesia berdasarkan asas Desentralisasi, asas Dekonsentrasi dan Tugas Pembantuan apakah sudah berjalan maksimal dengan memperhatikan kesejahteraan masyarakat di daerahnya serta apakah dengan adanya otonomi daerah juga meningkatkan kerjasama pembangunan antar daerah dalam kerangka Negara Kesatuan Republik Indonesia. Untuk melihat itu semua perlu adanya pengkajian mengenai otonomi daerah, kesejahteraan masyarakat dan kerjasama pembangunan daerah di Indonesia, sehingga tujuan penelitian dan manfaatnya dapat tercapai.

Pemahaman asas Desentralisasi diklasifikasikan (1) sebagai penyerahan kekuasaan dan kewenangan, (2) sebagai 
pelimpahan kekuasaan dan kewenangan, (3) sebagai pembagian, penyebaran, pemencaran, dan pemberian kekuasaan dan kewenangan, (4) sebagai sarana dalam pembagian pembentukan daerah pemerintahan (Agussalim Andi Gadjong, 2007: 79). Menurut Bagir Manan bahwa Desentralisasi dilihat dari hubungan pusat dan daerah tidak boleh mengurangi hak-hak rakyat daerah dalam penyelenggaraan pemerintahan daerahnya, tidak boleh mengurangi hak rakyat daerah untuk berinisiatif atau berprakarsa dalam hubungan antar pusat dengan daerah dan antar daerah dengan daerah dapat berbeda, kemudian hubungan antara pusat dan daerah dalam rangka mewujudkan keadilan dan kesejahteraan sosial di daerah. (Bagir Manan, 1990).

Konsep Desentralisasi secara umum dapat dikategorikan dua perspektif yaitu Political And Adminstrative Desentralitation Perspectives (Perspektif Desentralisasi Politik dan Desentralisasi Administratif) (Samsudin Haris, 2006: 68). Asas Desentralisasi sebenarnya masih melekat pada pemerintah pusat oleh karena itu asas Desentralisasi bukan merupakan suatu sistem yang berdiri sendiri melainkan rangkaian dari sistem yang sudah terbangun sebelumnya yaitu "sentralisasi", menurut Herbert $H$, Werline bahwa sesungguhnya Desentralisasi tidak akan terjadi tanpa sentralistik, dengan demikian sentralisitik ini merupakan titik awal lahir Desentralisasi (Titik Tri Wulan, 2006: 186).

Penerapan asas Desentralisasi menurut Bagir Manan bersifat kepegawaian (ambtelijk) untuk melancarkan penyelenggaraan pemerintahan sentral di daerah (Titik Tri Wulan, 2006:186). Dalam Pasal 1 ayat (8) UndangUndang Nomor 32 Tahun 2004 Tentang Pemerintahan Daerah bahwa Dekonsentrasi adalah pelimpahan wewenang pemerintahan oleh pemerintah pusat kepada Gubernur sebagai wakil pemerintah dan/atau kepada instansi vertikal di wilayahnya [Undang-Undang Nomor 32 Tahun 2004, Pasal 1 ayat (8)].

Pelaksanaan asas Dekonsentrasi, merupakan asas dalam sistem penyelenggaraan pemerintahan tidak semuanya urusan pemerintah pusat diserahkan kepada pemerintah daerah menurut asas Desentralisasi tapi ada urusan yang tidak diserahkan sebagaimana yang diatur dalam Pasal 10 ayat (2), (3) bahwa tugas pembantuan (medebewind) yang menjadi urusan pemerintah pusat yang tidak diberikan adalah (a) politik luar negeri, (b) pertahanan, (c) keamanan, (d) yustisi, (e) moneter dan fiskal, (f) agama, dengan demikian telah jelas asas penyelenggaraan pemerintahan daerah dalam pelaksanaannya menggunakan asas otonomi dan tugas pembantuan, dengan demikian secara teoritis tujuan dari Desentralisasi untuk menciptakan pemerintah yang efektif, efisien, membangun demokrasi lokal, dan menghargai keragaman lokal yang tujuan akhirnya menciptakan kesejahteraan rakyat (Sutoro: disampaikan dalam Diskusi Publik "Suara Dari Daerah: Mendekatkan Negara pada Pemenuhan Kebutuhan Dasar Warga" Kerjasama Perkumpulan Prakarsa dan YAPPIKA, Jakarta 11 Oktober 2006). Dalam asas Desentralisasi ini bagi pemerintah daerah diberikan ruang untuk melaksanakan kerjasama antar daerah yang diatur dalam keputusan bersama.

\section{Konstruksi Konsepsional Otonomi Daerah sebagai Salah Satu Instrumen Peningkatan Laju Pertumbuhan Kesejahteraan Masyarakat di Indonesia}

Konsep Otonomi Daerah diberlakukan sejak awal Kemerdekaan dan pada masa kolonial Belanda. Pembahasan dalam penelitian ini berdasarkan pada Undang-Undang Nomor 22 Tahun 1999 dan Undang-Undang Nomor 32 Tahun 2004 Tentang Pemerintahan Daerah.

Undang-Undang Nomor 22 Tahun 1999 menganut prinsip otonomi daerah yang luas, nyata, dan bertanggung jawab, untuk mengatur dan mengurus kepentingan masyarakat menurut prakarsa sendiri berdasarkan aspirasi masyarakat. Adapun Prinsip-prinsip yang dianut dalam UndangUndang Nomor 22 Tahun 1999: (1) Penyelenggaraan menitikberatkan pada aspek demokrasi, keadilan, pemerataan, serta potensi dan keanekaragaman daerah; (2) Berdasarkan pada otonomi luas, nyata dan bertanggungjawab; (3) Diletakkan otonominya pada daerah kabupaten dan daerah kota; (4) Berdasarkan pada konstitusi; (5) Meningkatkan kemandirian daerah otonom tidak ada wilayah administratif dalam daerah kabupaten dan daerah kota; (6) Lebih meningkatkan peran dan fungsi Badan Legislatif Daerah; (7) Asas Dekonsentrasi diletakkan pada daerah provinsi dalam kedudukannya sebagai wilayah administrasi untuk melaksanakan pemerintahan tertentu yang dilimpahkan kepada Gubernur sebagai wakil pemerintah; (8) Pelaksanaan asas Tugas Pembantuan dimungkinkan tidak hanya dari pemerintah kepada daerah, tapi juga dari pemerintah dan daerah kepada desa.

Penerapan Undang-Undang yang berkaitan dengan otonomi daerah dalam implementainya termasuk Undang-Undang No.2 Tahun 1999, terdapat permasalahan dalam pembangunan nasional Indonesia yang tidak dapat dihindari adanya jurang antara sikaya dan si miskin sehingga kesejahteraan yang diharapkan tidak dapat tercapai, hal ini karena akibat terbatasnya peraturan pelaksanaan sebagai juklak dan juknis serta akibat asas-asas otonomi daerah di abaikan 
dapat menghambat usaha pembangunan di daerah (Lihat CFG. Sunaryati Hartono, 1998: 76-79).

Regulasi yang mengatur tata
penyelenggaraan pemerintah daerah saat ini sebagai hukum positif (J.B. Dalio, 2001: 7) adalah UU Nomor 32 Tahun 2004 juncto UU Nomor 3 Tahun 2005 juncto UU Nomor 8 Tahun 2005 juncto UU Nomor 8 Tahun 2008 tentang Perubahan atas Undang-Undang Nomor 32 tahun 2004.

Pelaksanaan otonomi daerah sangat dipengaruhi juga oleh faktor-faktor kemampuan si pelaksana, kemampuan dalam keuangan, ketersediaan alat dan bahan, faktor potensi dan geografi, dan kemampuan dalam berorganisasi. Secara garis besarnya, pelaksanaan otonomi daerah ini hanya meliputi pada prinsip demokrasi, keadilan, pemerataan dan keanekaragaman, sedangkan untuk politik luar negeri, pertahanan keamanan, peradilan, moneter, fiskal dan agama kewenangan urusan pemerintah yang tidak diberikan ke daerah (Josef Riwu Kaho, 2003: 65). Prospek otonomi ke depan dapat dilakukan dengan beberapa pendekatan yaitu dari aspek ideologi, politik, sosial budaya dan pertahanan keamanan.

Aspek Ideologi, mengandung falsafah bangsa yaitu Pancasila sebagai pandangan hidup dan dasar negara, mengandung nilai-nilai pengakuan pada Ketuhanan, Persatuan dan Kesatuan terhadap hak asasi manusia, demokrasi, keadilan dan kesejahteraan sosial bagi seluruh masyarakat, nilai-nilai ini dalam penyelenggaraan pemerintahan daerah (otonomi daerah) dapat diterima dalam kehidupan berbangsa dan bernegara.

Aspek Politik, adanya pemberian otonomi dan kewenangan kepada daerah merupakan suatu wujud pengakuan dan kepercayaan dari pusat kepada daerah, pengakuan dan kepercayaan ini dapat menciptakan hubungan yang harmonis antara pusat dan daerah serta memperkuat persatuan dan kesatuan bangsa, setiap kebijakan otonomi ini daerah yang berkaitan dengan aspek politik merupakan suatu upaya pendidikan politik rakyat yang dampaknya adanya peningkatan kehidupan politik di daerah.

Aspek Ekonomi, dalam tujuan pemberdayaan kapasitas daerah akan memberikan kesempatan kepada daerah untuk mengembangkan dan meningkatkan perekonomian di daerah yang berpengaruh secara signifikan dalam peningkatan kesejahteraan rakyat di daerah sesuai dengan kondisi dan kemampuan serta kebutuhannya, kemudian otonomi daerah sebagai instrumen dalam penyelenggaran pemerintahannya dapat memberikan pelayanan secara maksimal kepada para pelaku ekonomi di daerah, baik lokal, regional, nasional maupun internasional. Sebagaimana yang dikemukakan Ade Maman Suherman dalam tantangan Indonesia masa mendatang (2002:33)
Aspek Sosial Budaya, nilai-nilai yang terkandung dalam aspek sosial budaya ini yang beranekaragam di daerah sebagai suku bangsa merupakan suatu nilai yang sangat penting bagi eksistensi daerah, bahwa dengan adanya pengakuan dari pemerintahan pusat maka daerah akan merasa setara dan sejajar dengan suku bangsa lainnya, hal ini akan sangat berpengaruh dalam upaya mempersatukan bangsa dan negara yang pada akhirnya nilai budaya lokal dengan keanekaragamannya akan memperkaya khasanah budaya nasional.

Aspek Pertahanan dan Keamanan, otonomi dengan kewenang-kewenangannya dapat memantapkan kondisi ketahanan daerah dalam kerangka ketahanan nasional akan menumbuhkan kepercayaan daerah terhadap pusat yang dapat mengeliminir gerakan separatis yang ingin memisahkan diri dari Negara Kesatuan Republik Indonesia.

Memerhatikan pendekatan aspek-aspek tersebut diatas, secara ideal kebijakan otonomi daerah merupakan kebijakan yang sangat tepat dalam pemerintahan di daerah di masa mendatang dalam menghadapi segala tantangan penyelenggaraan kehidupan bermasyarakat, berbangsa dan bernegara. Pembagian kewenangan dalam sistem pemerintahan otonomi daerah perlu kejelasan karena akan menyangkut dengan pembagian wilayah yang diikuti dengan kewenangan-kewenangan kontekstualnya dengan geografi dan potensi-potensi daerah yang berbeda-beda setiap provinsi, kabupaten, kota dan desa. Untuk mewujudkannya ada beberapa kriteria meliputi: (1) Eksternalitas, adalah pendekatan dalam budaya urusan pemerintah secara komprehensif antara kewenangan daerah yang diberikan otonomi dan Pemerintah Pusat (pemerintahan pusat dan daerah otonomi) secara maksimal dan regional. (2) Akuntabilitas, adalah pendekatan dalam berbagai pembagian urusan pemerintahan secara internal yang langsung lebih dekat dampak/akibat dari urusan yang ditanganinya, sehingga masyarakat akan lebih terjamin. (3) Efisiensi, pendekatan ini berkaitan dengan urusan mempertimbangkan tersedianya sumber daya (personil), dana, dan perwakilan untuk mendapatkan ketepatan, kepastian dan kecepatan hasil yang harus di capai dalam penyelenggaraan urusan tersebut antara daerah otonomi dengan daerah otonomi serta antara daerah otonomi dengan daerah otonomi dalam kerjasama antar daerah yang berdaya guna dan hasil daya gunanya dapat dirasakan manfaatnya oleh masyarakat.

\section{Faktor-faktor yang Memengaruhi Pelaksanaan Otonomi Daerah}

Pada umumnya faktor-faktor yang 
mempengaruhi keberhasilan otonomi daerah adalah kemampuan keuangan (finansial), kemampuan manajemen, kondisi sosial budaya masyarakat dan karakteristik ekologis, Riwo Kaho mengidentifikasikan faktor-faktor yang berpengaruh dan sangat menentukan penyelenggaraan otonomi daerah antara lain (Dharma Setyawan Salam, 2004:108):

(a) Sumber daya manusia dan kemampuan aparatur serta partisipasi masyarakat; (b) Keuangan yang stabil terutama pendapatan asli daerah; (c) Peralatan yang lengkap; (d) Organisasi dan manajemen yang baik.

Menurut Smith (Dharma Setyawan Salam, 2004: 108) bahwa keberhasilan pelaksanaan otonomi daerah terletak pada fungsi atau tugas pemerintahan, kemampuan pemungutan pajak daerah, bidang tugas administrasi, jumlah pelimpahan wewenang, besarnya anggaran belanja, wilayah, ketergantungan keuangan, dan personil. Kemudian urusan yang dapat menjadi urusan Rumah Tangga Daerah yang sifatnya telah melekat dalam suatu daerah, yang dapat menumbuhkan partisipasi masyarakat, menyangkut kepentingan langsung masyarakat mengikut sertakan banyak sumber daya manusia, menambah penghasilan daerah yang bersangkutan dan memerlukan penanganan pengambilan keputusan negara ( $B$. Hestu Cipto Handoyo, 1998; 7-8).

\section{Keefektifan Strategi Pelaksanaan Otonomi Daerah}

Menurut Epstein, paling tidak ada empat kriteria untuk mengukur keefektifan suatu pemerintahan daerah (Dharma Setyawan Salam, 2004: 108) diantaranya:

(a) Kebutuhan masyarakat secara implisit dapat dikontrol; (b) Adanya program layanan khusus yang dapat memenuhi kebutuhan masyarakat; (c) Mengukur kualitas layanan pemerintahan daerah terutama dengan ukuran kepuasan dan persepsi masyarakat; (d) Pemberian pelayanan harus dapat menyesuaikan diri dengan masalah-masalah yang ada di masyarakat.

Mengukur keberhasilan suatu pembangunan dari suatu pemerintahan tidak cukup dengan menggunakan tolok ukur ekonomi saja, apabila tidak dapat mengurangi kemiskinan, memperkecil ketimpangan pendapatan serta menyediakan lapangan kerja yang cukup bagi penduduknya, melainkan harus di dukung oleh indikator-indikator sosial (non ekonomi) antara lain seperti tingkat mengerti huruf, tingkat pendidikan, kualitas pelayanan kesehatan, kecukupan akan kebutuhan perumahan. Adapun menurut Todaro, yang dimaksud dengan keberhasilan pembangunan ekonomi paling tidak ada 3 (tiga) indentifikasi yang dapat dilihat, yaitu: (1) Berkembangnya kemampuan masyarakat untuk memenuhi kebutuhan pokok (basic needs); (2) Meningkatnya rasa harga diri (self esteem) masyarakat sebagai manusia; dan (3) Meningkatnya kemampuan masyarakat untuk memilih (freedom from servitude).

Menurut Surna (Akadun, tentang Revitalisasi Forum Musrenbang sebagai wahana partisipasi masyarakat dalam perencanaan pembangunan daerah, Mimbar, Vol. XXVII, No. 2, Desember 2011) bahwa pembangunan adalah kegiatan yang direncanakan dalam mengolah sumber daya alam dan sumber daya manusia dengan memanfaatkan iptek untuk kelangsungan hidup manusia. Kemudian menurut Siagian bahwa pemerintah dalam proses pembangunan sebagai Stabilisator, Inovator, Modernisator dalam pembangunan di daerahnya.

Format Ideal Kerjasama Pembangunan Antara Daerah di Indonesia Berdasarkan Undang-Undang Nomor 32 Tahun 2004

Landasan filosofi yang melatarbelakangi lahirnya Undang-Undang Nomor 22 Tahun 1999 Tentang Pemerintahan Daerah bahwa dalam penyusunan undang-undang tersebut sangat dipengaruhi oleh euforia demokrasi yang dipicu oleh perubahan keadaan politik yang begitu cepat, sehingga dalam upaya mengatur kebijakan Desentralisasi dan Otonomi Daerah kurang sempurna, baik dalam menafsirkan isi dan substansi undang-undang tersebut, maupun pada implementasinya di lapangan, muncul persoalan yang kompleks dan multidimensional, terjadinya kesimpangsiuran pemahaman dan pengkotakkotakan dalam penyelenggaraan otonomi daerah yang akan menimbulkan inefisiensi dalam penyelenggaraan pemerintahan daerah, hubungan yang tidak serasi antara pemerintahan pusat, pemerintahan provinsi, pemerintahan kabupaten dan pemerintahan kota yang berakibat persatuan dan kesatuan bangsa melemah dan menimbulkan disintegrasi bangsa.

Undang-Undang Nomor 32 Tahun 2004 telah memberikan peluang kepada daerah untuk mengatur dan mengurus sendiri urusan pemerintahan menurut asas otonomi dan tugas pembantuan yang diarahkan untuk mempercepat terwujudnya kesejahteraan masyarakat melalui peningkatan pelayanan, pemberdayaan dan peran serta masyarakat serta peningkatan daya saing daerah melalui kerjasama antar pemerintah daerah dengan pihak ketiga saling menguntungkan.

Pada Pasal 195 Undang-Undang Nomor 32 Tahun 2004 tentang Pemerintahan Daerah: (1) bahwa dalam rangka meningkatkan kesejahteraan rakyat, daerah dapat mengadakan kerjasama dengan daerah lain yang didasarkan pada pertimbangan efisiensi dan efektifitas pelayanan 
publik, sinergi dan saling menguntungkan; (2) bahwa kerjasama sebagaimana dimaksud pada ayat (1) dapat diwujudkan dalam bentuk badan kerjasama antar daerah yang diatur dengan keputusan bersama; (3) Dalam penyediaan pelayanan publik, daerah dapat bekerjasama dengan pihak ketiga; (4) Kerjasama sebagaimana dimaksud pada ayat (1) dan ayat (3) membebani masyarakat dan harus mendapat persetujuan DPRD.

Pada konteks yuridis, amanat UndangUndang Nomor 32 Tahun 2004 ditindaklanjuti pengaturannya dengan Peraturan Pemerintah Nomor 50 Tahun 2007 Tentang Tata Cara Pelaksanaan Kerjasama Daerah dan secara empiris telah cukup banyak daerah yang melakukan dan melaksanakan kerjasama ini, termasuk kerjasam dengan luar negeri yang telah diatur terlebih dahulu dalam Undang-Undang Nomor 24 Tahun 2000 Tentang Perjanjian Internasional. Sebagaimana dikemukakan Ade Maman Suherman dalam rangka Indonesia melakukan kerjasama internasional dalam bidang ekonomi (2002: 33).

\section{Simpulan dan Saran}

Otonomi daerah dapat menjadi salah satu instrumen dalam peningkatan lajunya pertumbuhan kesejahteraan masyarakat di Indonesia, apabila pembangunan di daerah mengacu pada potensi daerah atau geografis, tata pemerintahan, terutama yang berkaitan dengan birokrasi, pemerintahan itu sendiri, dengan melaksanakan prinsip standar pelayanan minimal yang dilaksanakan oleh pemerintah daerah yang menjamin peningkatan mutu pelayanan masyarakat secara merata sehingga kesejahteraan masyarakat menjadi semakin baik, pengembangan kehidupan demokrasi, keadilan, pemerataan serta pemeliharaan hubungan yang serasi antara pusat dan daerah serta antara daerah dengan daerah dalam menjaga keutuhan Negara Kesatuan Republik Indonesia.

Format ideal kerjasama pembangunan antara daerah di Indonesia berdasarkan Undang-Undang Nomor 32 tahun 2004 didasarkan pada pertimbangan efisiensi dan efektifitas pelayanan publik, sinergi dan saling menguntungkan dalam bentuk badan kerjasama antar daerah yang diatur dengan keputusan bersama tanpa membebani masyarakat dan harus mendapatkan persetujuan DPRD, aturan yang ideal harus mengacu pada budaya, substansi, struktur, dengan tidak menghilangkan makna kebangsaan.

Setiap daerah harus memiliki peraturan daerah yang mengatur mengenai kerjasama pembangunan antar daerah sebagai landasan norma dalam melaksanakan kerjasama antar daerah. Selain kerjasama pembangunan antar daerah juga, dapat dirintis kerjasama daerah dengan luar negeri.

\section{Daftar Pustaka}

Ade Maman Suherman, (2002). Aspek Hukum Dalam Ekonomi Global. Ghalia Indonesia, cetakan I, Jakarta.

Agussalim Andi Gadjong, (2007). Pemerintahan Daerah, Kajian Politik dan Hukum (Analisis Perundang-undangan Pemerintah Daerah dan Otonomi Daerah Semenjak Tahun 1945 sampai dengan 2004). Ghalia Indonesia, Cetakan I, Ciawi Bogor.

Bagir Manan, (1990). Hubungan Antara Pusat dan Daerah Berdasarkan Azas Desentralisasi Menurut UUD 1945. Diesertasi, UNPAD, Bandung.

B. Hestu Cipto Handoyo, (1998). Otonomi Daerah, titik berat otonomi dan Urusan Rumah Tangga Daerah. cetakan pertama, Penerbit Irma Jaya, Yogyakarta.

Bambang Sunggono, (2009). Metodologi Penelitian Hukum. PT. RajaGrafindo Persada, Jakarta.

C.F.G. Sumaryati Hartono, (1998). Hukum Ekonomi Pembangunan Indonesia. Cetakan Kedua, Bina Cipta, Bandung.

Dharma Setyawan Salam, (2004). Otonomi Daerah Dalam Perspektif Lingkungan, Nilai dan Sumber Daya. Cetakan Dua, Djambatan, Bandung.

J.B. Dalio, (2001). Pengantar Hukum Indonesia. PT. Prenhallindo, Jakarta.

Josef Riwu Kaho, (2003). Prospek Otonomi di Indonesia. Fisipol UGM, Yogyakarta.

Samsudin Haris, (2006). Membangun Format Baru Otonomi Daerah. Cetakan Satu, Jakarta LIPI Press.

Soehino, (2000). Ilmu Negara.Penerbit Liberty, Yogyakarta.

Soeryono Soekanto, (1986). Pengantar Penelitian Hukum. UI Press, Cetakan ketiga, Jakarta.

Titik Tri Wulantutik, (2006). Pokok-Pokok Hukum Tata Negara. Cetakan Satu, Prestasi Pustaka, Jakarta.

Zainuddin Ali, (2009). Metode Penelitian Hukum. Sinar Grafika, Jakarta.

Republik Indonesia, Undang-Undang Dasar 1945 Pasca Amandemen.

Republik Indonesia, Undang-Undang Republik Indonesia Nomor 32 Tahun 2004 tentang Pemerintahan Daerah.

Republik Indonesia, Peraturan Pemerintah Republik Indonesia Nomor 50 Tahun 2007 tentang Tata Cara Pelaksanaan Kerjasama Daerah.

Republik Indonesia, Peraturan Pemerintah Republik Indonesia Nomor 7 Tahun 2008 tentang Dekonsentrasi dan Tugas Pembantuan. 